\title{
MESTERTANÁRKÉPZÉS - TUDOMÁNYTERÜLETEK - FELADATOK
}

\section{LUDÁNYI ÁGNES}

\author{
az Eszterházy Károly Főiskola főiskolai tanára \\ lag@ektf.hu
}

Az Eszterházy Károly Főiskola Tanárképzési és Tudástechnológiai Kara minden évben Kari Tudományos Tanácskozást szervez. Idén, az aktualitásnak megfelelően a mestertanárképzés került a rendezvény fókuszába. A mestertanárképzés programjának kialakításában évek óta dolgoznak a kar oktatói, amit segített a HEFOP 3.3.2 pályázat, hiszen a kompetencia-alapú oktatás felsőoktatási háttere kidolgozódott. Természetesen ez önmagában nem jelentette azt, hogy minden kérdéskör tisztázódott, viszont körvonalazódtak azok a területek, ahol további differenciálás szükséges, vagy további oktatói-kutatói együttmüködést kell kidolgozni.

A kerekasztal beszélgetés témája a kompetencia-alapú programok jellemzőinek egyeztetése volt.

Felmerült, hogy a gyakorlatorientált, tanulásközpontú programok milyen módon egyeztethetőek és adaptálhatók a felsőoktatás müködési módjával. Ez a kérdéskör szorosabb együttmüködést, és más típusú munkamódot igényel a gyakorlóiskolai és egyéb közoktatási intézményekkel. A mestertanárképzésben részt vevő hallgatók felkészítése, a szakmailag védhető portfólió tervezésére és védésére, szintén vet fel módszertani kérdéseket, és ezeket is érintette a tanácskozás. Nem elhanyagolható feladat az sem, hogy a hagyományos képzés tantárgy/tudományterületi/ felaprózottsága már nem követhető, ezért a képzésben részt vevő oktatók tartalmi egyeztetései elengedhetetlenek. Csak ilyen munkamóddal valósítható meg, hogy a pályaszocializáció szempontjából kitüntetett képzési idő, valóban integrált egységben dolgozza ki a hallgatók nézeteit a szakmáról, tanárságról. Ennek feltétele, hogy a pedagógia, a pszichológia tanegységeket oktatók közösen értelmezzenek képzési célokat, abban konszenzusra jussanak, és a célokhoz rendelhető feladatokban is egységesek legyenek. Ennek az előkészítését és kidolgozását egy szervezetfejlesztő munka már megelőzte, de az első évfolyamok diplomaszerzéséig, folyamatossá kell tenni, hiszen a tapasztalatok beépítése elengedhetetlen.

A konferencia másik lényeges célja volt, hogy a tanárképzésben dolgozó fiatal doktoranduszok megismertessék kutatási témáikat a hallgatósággal és egymással természetesen. Ez a programrész különösen sikeresnek mondható, mert azt a pluszfunkciót tudta vállalni, hogy az új típusú tanárképzéshez adekvát pedagóguskutatásokat prezentált. 
A témákból néhány, amelyek a mestertanárképzés szempontjából a leglényegesebbek:

- A tanár-szerep bővülése újabb szerepelemekkel, különös tekintettel a gyermekvédelmi tevékenységhez kapcsolódó szerepelvárásokra.

- Az elektronikus tananyagok készítésének, használhatóságának kérdésköre.

- A tanulás-tanítás módszertani megújítása.

- Csoportmódszerek alkalmazásának lehetőségei, új tevékenységformák elemzése.

- Nemzetközi pályaorientációs vizsgálatok eredményei.

- A multikulturalitás megjelenése a felsőoktatásban.

- Pedagógus-személyiségvizsgálat a kompetencia-alapú oktatás szempontjainak figyelembevételével.

Fenti kutatási témák beépülése a mesterszintü tanárképzésbe folyamatos, mert amellett hogy az elökutatások ezekben a témakörökben már lezajlottak, kipróbálásuk, és az eredmények ismeretében végzett korrekciójuk még újabb feladatokat jelölnek ki.

Összességében elmondható, hogy a tudománynapi rendezvény fókuszában egyértelműen a megújuló tanárképzés legfontosabb szakmai kérdései szerepeltek. Emellett, lehetőség teremtődött a neveléstudomány, pszichológia, szakmódszertan oktatói számára, hogy az egységes fogalomrendszer kidolgozását, konszenzusos értelmezését elvégezzék a tanárképzés színvonalának emelése érdekében. 